\title{
FAKTOR - FAKTOR YANG MEMPENGARUHI TINGKAT INFLASI DI INDONESIA
}

\author{
Siti Marliah \\ Dosen STIE Bisnis Indonesia, Jakarta
}

\begin{abstract}
This thesis analyzes the effect of interest SBI rate, money supply, exchange rate, economic growth, gross domestic product (GDP), government expenditure towards the inflation rate in Indonesia during the period from 2005 to 2010. The data used in this study secondary data obtain data that have been published by the Central Statistics Agency (BPS) and Bank Indonesia and agencies / institutions. The technique analysis used is error correction model (ECM) analysis method with the help of E-views 5.1. The results of this study indicate that the SBI variable had no significant effect on inflation, but SBI $t-2$ can affect inflation in the short-term regression model while the long-term regression model was not significant. Variable JUB significant effect on inflation in the short term while the regression models $J U B t-2$ no significant effect on inflation in the regression model of short term and long term. exchange rate and exchange rate $t-2$ had no significant effect on inflation and short-term regression model longterm regression model. Growth of GDP and GDP Growth t-2 had no significant effect on inflation and short-term regression model long-term regression model. GDP significant effect on inflation in the short-term regression model while GDP $t-2$ had no significant effect on the inflation regression model short term and long term. Government Spending and Government Spending T-2 had no significant effect on inflation, while short-term regression model on the long-term regression model variables no significant government spending.

Keywords : Inflation, SBI, JUB, Exchange Rate, Economic Growth, GDP and Government Expenditure.
\end{abstract}

\begin{abstract}
Abstrak: Tesis ini menganalisa pengaruh tingkat suku bunga SBI, jumlah uang beredar, nilai tukar rupiah, pertumbuhan ekonomi, produk domestik bruto (PDB) dan pengeluaran pemerintah terhadap tingkat inflasi di Indonesia selama kurun waktu 2005 - 2010. Data yang digunakan dalam penelitian ini adalah data sekunder yang telah dipublikasikan oleh Badan Pusat Statistik (BPS) dan Bank Indonesia serta instansi / lembaga lainnya Adapun teknik analisis yang digunakan adalah error correction model (ECM) dengan bantuan program E-views 5.1. Hasil dari penelitian ini menunjukan bahwa variabel SBI tidak berpengaruh signifikan terhadap inflasi namun SBI pada t-2 dapat mempengaruhi inflasi pada model regresi jangka pendek sedangkan pada model regresi jangka panjang tidak berpengaruh signifikan. Variabel JUB berpengaruh signifikan terhadap inflasi pada model regresi jangka pendek sedangkan JUB t-2 tidak berpengaruh siginifikan terhadap inflasi pada model regresi jangka pendek dan jangka panjang. Nilai Tukar dan Nilai Tukar t-2 tidak berpengaruh signifikan terhadap inflasi pada model regresi jangka pendek dan model regresi jangka panjang. Pertumbuhan PDB dan Pertumbuhan PDB t-2
\end{abstract}


tidak berpengaruh signifikan terhadap inflasi pada model regresi jangka pendek dan model regresi jangka panjang. PDB berpengaruh signifikan terhadap inflasi pada model regresi jangka pendek sedangkan PDB t-2 tidak berpengaruh signifikan terhadap inflasi pada model regresi jangka pendek dan jangka panjang. Pengeluaran Pemerintah dan Pengeluaran Pemerintah t-2 tidak berpengaruh signifikan terhadap inflasi pada model regresi jangka pendek sedangkan pada model regresi jangka panjang variabel Pengeluaran Pemerintah tidak berpengaruh signifikan.

Kata kunci: Inflasi, SBI, JUB, Nilai Tukar, pertumbuhan PDB, PDB dan Pengeluaran Pemerintah.

\section{PENDAHULUAN}

Dalam perekonomian terdapat satu peristiwa moneter yang penting dan hampir dijumpai semua negara didunia adalah inflasi. Inflasi berasal dari bahasa latin "inflance" yang berarti meningkatkan. Secara umum inflasi adalah perkembangan dalam perekonomian, dimana harga dan gaji meningkat, permintaan tenaga kerja melebihi penawaran dan jumlah uang yang beredar sangat meningkat. Inflasi selalu ditandai dengan peningkatan harga-harga secara cepat (Ensiklopedia Indonesia : 1991, 445). Inflasi merupakan proses kenaikan harga barang-barang secara umum dan berlaku terus-menerus. Ini tidak berarti bahwa harga berbagai macam barang itu naik dengan persentase yang sama. Mungkin dapat terjadi kenaikan harga umum barang secara terus-menerus dalam periode tertentu, kenaikan yang terjadi hanya sekali saja (meskipun dalam persentase yang cukup besar) bukan merupakan inflasi (Nopirin,1992: 25). Pada masa krisis terutama tahun 1998, Indonesia mengalami inflasi tertinggi yaitu mencapai 77,6 \%. Peningkatan laju inflasi terutama disebabkan oleh depresiasi nilai tukar rupiah dan krisis ekonomi yang membuat sentimen konsumen serta terhadap inflasi yang tinggi. Sebelumnya Indonesia pernah mengalami hiper inflasi pasa masa akhir orde lama yaitu pada tahun 1966, Inflasi mencapai 6,35 \% . Sehingga secara psikologi inflasi merupakan momok bagi masyarakat indonesia (Soesilo, 2002 :1). Secara umum inflasi menyebabkan timbulnya sejumlah biaya sosial yang harus ditanggung oleh masyarakat. Pertama, inflasi menimbulkan dampak pada distribusi pendapatan. Masyarakat golongan bawah dan berpendapatan tetap akan menanggung beban inflasi dengan turunnya daya beli mereka. Sebaliknya, masyarakat menengah dan atas yang memiliki aset-aset finansial seperti tabungan dan deposito dapat melindungi kekayaanya dari inflasi, sehingga daya beli mereka relatif tetap. Kedua, inflasi yang tinggi berdampak negatif terhadap pertumbuhan ekonomi. Tingkat inflasi tinggi sering diikuti oleh tingkat inflasi yang berfluktuasi yang dalam jangka panjang memberikan dampak negatif terhadap laju pertumbuhan ekonomi. Hal ini dapat terjadi karena ketidakpastian tingkat inflasi yang menyebabkan investasi cenderung untuk melakukan investasi finansial jangka pendek yang bersifat spekulatif daripada melakukan investasi proyek rill yang bersifat produktif. Berdasarkan latar belakang yang telah diuraikan diatas, maka penulis mengambil judul "Faktor-Faktor Yang Mempengaruhi Tingkat Inflasi di Indonesia”.

\section{LANDASAN TEORI}

\subsection{Tingkat Suku Bunga SBI (Sertifikat Bank Indonesia)}

Tingkat suku bunga adalah harga dari penggunaan uang atau bisa juga disebut sewa atas penggunaan uang untuk jangka waktu tertentu. Apabila jumlah dana yang ditawarkan kreditur lebih kecil daripada yang diminta debitur, maka tingkat bunga cenderung naik, begitu juga sebaliknya (Boediono, 1999). Tingkat bunga keseimbangan yang sesungguhnya adalah tingkat 
bunga yang merupakan tingkat bunga keseimbangan di pasar investasi dan sekaligus merupakan tingkat bunga keseimbangan di pasar uang, tingkat bunga ini juga disebut tingkat bunga murni. Selanjutnya dari tingkat bunga murni akan melahirkan beberapa macam tingkat bunga diantaranya adalah tingkat bunga Nominal, tingkat bunga riil, dan tingkat bunga riil fisher.

\subsection{Jumlah Uang Yang Beredar}

Pengertian jumlah uang yang beredar adalah seluruh uang kartal dan uang giral yang tersedia untuk digunakan oleh masyarakat. Pengertian paling sempit dari jumlah uang beredar adalah uang kertas dan uang logam yang ada di tangan masyarakat. Definisi tentang jumlah uang beredar adalah sebagai berikut:

$$
\begin{aligned}
& \mathrm{M}_{1}=\mathrm{C}+\mathrm{DD} \\
& \mathrm{M}_{2}=\mathrm{M}_{1}+\mathrm{TD}+\mathrm{SD} \\
& \mathrm{M}=\text { Money (Uang) } \\
& \mathrm{C}=\text { Currency (Uang Kartal) } \\
& \mathrm{DD}=\text { Demand Deposit (Uang Giral) } \\
& \mathrm{TD}=\text { Time Deposit (Deposito Berjangka) } \\
& \mathrm{SD}=\text { Saving Deposit (Saldo Tabungan) }
\end{aligned}
$$

\subsection{Nilai Tukar (Exchange Rate)}

Nilai tukar adalah sejumlah uang dari suatu mata uang tertentu yang dapat dipertukarkan dengan satu unit mata uang negara lain. Dalam ekonomi internasional, penting diperhatikan tentang konvertibilitas uang (currency convertibility), yaitu penggunaan mata uang yang dapat dengan mudah ditukarkan dengan mata uang lain yang biasa disebut dengan istilah International Convertible Currency. Penentuan nilai tukar merupakan suatu hal penting bagi perekonomian suatu negara karena hal tersebut merupakan satu alat yang dapat digunakan untuk mendorong pertumbuhan ekonomi dan mengisolasi perekonomian suatu negara dari gejolak perekonomian global. Pada dasarnya kebijakan nilai tukar yang ditetapkan suatu negara mempunyai beberapa fungsi utama (Oesman, 1999), yaitu :

a. Untuk mempertahankan keseimbangan neraca pembayaran dengan sasaran akhir menjaga kecukupan cadangan devisa.

b. Untuk menjaga kestabilan pasar domestik.

c. Sebagai instrumen moneter khusus bagi negara yang menerapkan suku bunga dan nilai tukar sebagai sasaran operasional kebijakan moneter.

d. Sebagai nominal anchor dalam pengendalian inflasi.

\subsection{Valuta Asing (Forex or Foreign Currency)}

Valuta asing (valas) atau foreign exchange (forex) atau foreign currency diartikan sebagai mata uang asing dan alat pembayaran lainnya yang digunakan untuk melakukan atau membiayai transaksi ekonomi keuangan internasional dan yang mempunyai catatan kurs resmi pada bank sentral (Hamdy, 1999). Mata uang yang sering digunakan sebagai alat pembayaran dan kesatuan hitung dalam transaksi ekonomi dan keuangan internasional disebut sebagai hard currency, yaitu mata uang yang nilainya relatif stabil dan kadang-kadang mengalami apresiasi atau kenaikan nilai dibandingkan dengan mata uang lainnya. 


\subsection{Pertumbuhan Ekonomi}

Menurut Putong (2002) pertumbuhan ekonomi adalah pertambahan output (pendapatan nasional) yang disebabkan oleh pertambahan alami dari tingkat pertambahan penduduk dan tingkat tabungan. Sedangkan menurut beberapa pakar ekonomi pembangunan, pertumbuhan ekonomi adalah merupakan istilah bagi negara yang telah maju untuk menyebut keberhasilan pembangunannya, sementara itu untuk negara yang sedang berkembang digunakan istilah pembangunan ekonomi.

\subsection{Produk Domestik Bruto}

PDB diartikan sebagai nilai keseluruhan semua barang dan jasa yang diproduksi di dalam wilayah tersebut dalam jangka waktu tertentu (biasanya per tahun). PDB berbeda dari produk nasional bruto karena memasukkan pendapatan faktor produksi dari luar negeri yang bekerja di negara tersebut. Sehingga PDB hanya menghitung total produksi dari suatu negara tanpa memperhitungkan apakah produksi itu dilakukan dengan memakai faktor produksi dalam negeri atau tidak. Sebaliknya, PNB memperhatikan asal usul faktor produksi yang digunakan. PDB Nominal (atau disebut PDB Atas Dasar Harga Berlaku) merujuk kepada nilai PDB tanpa memperhatikan pengaruh harga. Sedangkan PDB riil (atau disebut PDB Atas Dasar Harga Konstan) mengoreksi angka PDB nominal dengan memasukkan pengaruh dari harga. Analisa Mekanisme (kinerja) Ekonomi Nasional berdasar PDB melalui 3 pendekatan, yaitu:

1. Pendekatan Produksi

1. Pendekatan Pengeluaran / Pembelanjaan

3. Pendekatan Pendapatan.

\subsection{Pengeluaran Pemerintah}

Dalam kebijakan fiskal dikenal ada beberapa kebijakan anggaran yaitu anggaran berimbang, anggaran surplus dan anggaran defisit. Dalam pengertian umum, anggaran berimbang yaitu suatu kondisi di mana penerimaan sama dengan pengeluaran $(G=T)$. Anggaran surplus yaitu pengeluaran lebih kecil dari penerimaan $(G<T)$. Sedangkan anggaran defisit yaitu anggaran pengeluaran lebih besar dari penerimaan $(G>T)$. Anggaran surplus digunakan jika pemerintah ingin mengatasi masalah inflasi. Sedangkan anggaran defisit digunakan jika pemerintah ingin mengatasi masalah pengangguran dan peningkatan pertumbuhan ekonomi. Jika pemerintah merencanakan peningkatan pertumbuhan ekonomi untuk mengurangi angka pengangguran maka pemerintah dapat meningkatkan pengeluarannya. (Mangkoesoebroto, 1994).

\subsection{Inflasi}

Tingkat inflasi adalah kecenderungan naiknya harga secara umum dan terus menerus. Kenaikan harga dari satu atau dua barang saja tidak disebut inflasi, kecuali bila kenaikan tersebut meluas kepada (atau mengakibatkan kenaikan) sebagian besar dari barang-barang lain (Boediono, 2001).

Ada 2 (dua) alasan mengapa inflasi merupakan fenomena moneter :

(1). Inflasi yang cukup tinggi dibanyak negara berkembang, disebabkan oleh pertambahan pasokan uang yang cepat. Pertambahan ini disebabkan oleh besarnya defisit anggaran secara terus menerus akibat tidak cukupnya dana yang berasal dari pendapatan dalam negeri.

(2). Apapun penyebabnya, inflasi tidak dapat berlangsung secara terus menerus untuk jangka waktu yang lama tanpa adanya kenaikan dalam jumlah uang beredar.

Dalam konteks ini, berbagai faktor penyebab inflasi adalah sebagai berikut : 
(1). Demand pull inflation

(2). Cost - push inflation atau price - push inflation

(3). Import cost - push inflation

(4). Expectational inflation

(5). Internal inflation

\subsection{Kerangka Pemikiran}

Gambar 2.1

Skematik Kerangka Pemikiran

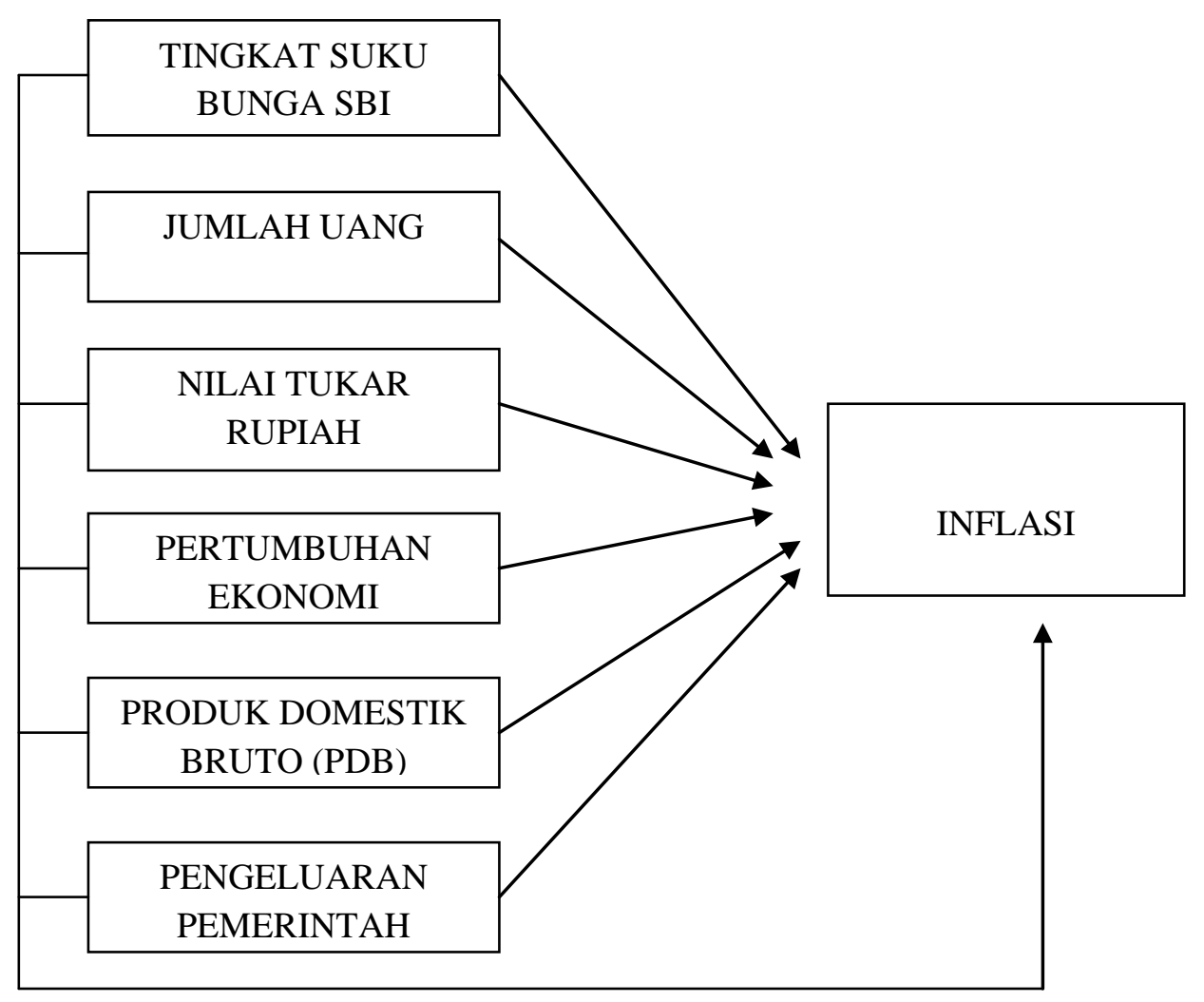

Sumber: Penulis 2014

\section{METODOLOGI PENELITIAN}

Metode yang digunakan dalam penelitian ini adalah metode penelitian korelasional melalui analisa regresi berganda. Penelitian ini juga dilakukan dengan mengkaji dan menganalisa secara logis masalah-masalah yang telah dirumuskan berdasarkan teori dan fakta yang relevan, sehingga secara sistemastis variabel-variabel yang terdapat dalam penelitian memperlihatkan hubungan sebagaimana adanya. Dalam penelitian ini peneliti menggunakan tehnik riset yaitu riset perpustakaan (library research), sedangkan instrumen yang digunakan merupakan data sekunder yang meliputi : tingkat inflasi, tingkat suku bunga SBI, jumlah uang beredar, nilai tukar rupiah, 
pertumbuhan ekonomi, produk domestik bruto dan pengeluaran pemerintah serta beberapa data lain yang mendukung. Sumber datanya didapatkan dari situs www.bps.go.id dimana peneliti mengambil data tingkat inflasi, tingkat suku bunga, jumlah uang beredar, nilai tukar rupiah, pertumbuhan ekonomi, produk domestik bruto dan pengeluaran pemerintah di Indonesia. Data yang diambil dari tahun 2005 sampai dengan 2010.

\subsection{Deskripsi Data}

Penelitian ini menggunakan data sekunder dimana definisi data sekunder adalah data yang diperoleh dari literatur-literatur dan data-data yang sudah dipublikasikan. Data bersumber dari www.bps.go.id dimana peneliti mengambil data tingkat inflasi, tingkat suku bunga, jumlah uang beredar, nilai tukar rupiah, pertumbuhan ekonomi, produk domestik bruto (PDB) dan pengeluaran pemerintah di Indonesia.

Tabel 3.1.

Definisi Operasional Variabel

\begin{tabular}{|c|c|c|c|}
\hline Variabel & Pengukuran & Skala & Sumber Data \\
\hline Dependent Variable & & & \\
\hline Laju Inflasi & Tingkat Inflasi (\%) & Rasio & Sekunder \\
(deperin.go.id)
\end{tabular}

Sumber : penulis (2012)

\subsection{Populasi Dan Sampel}

\subsubsection{Populasi}

Arikunto (2010:173) berpendapat bahwa populasi adalah keseluruhan subyek penelitian. Sedangkan menurut Sugiyono (2011:119), populasi dapat didefinisikan sebagai wilayah generalisasi yang terdiri dari obyek atau subyek yang mempunyai kuantitas dan karakteristik tertentu yang ditetapkan oleh peneliti untuk dipelajari dan kemudian ditarik kesimpulannya. Populasi adalah wilayah generalisasi yang berdiri dari: objek/subjek yang mempunyai kualitas 
dan karakteristik tertentu yang ditetapkan oleh penelitian untuk dipelajari dan kemudian ditarik kesimpulan.

\subsubsection{Sampel}

Sampel adalah bagian dari jumlah dan karakteristik yang dimiliki oleh populasi tersebut (Sugiyono, 2011:120). Sedangkan menurut pendapat lainnya, yang dimaksud sampel atau contoh adalah sebagian atau wakil populasi yang diteliti (Arikunto, 2010:174).

\subsection{Regresi Data Panel}

\subsubsection{Pengujian Asumsi Klasik}

Menurut Widarjono (2010:75), uji asumsi klasik digunakan untuk mengetahui apakah hasil analisis regresi linear berganda yang digunakan untuk menganalisis dalam penelitian ini terbebas dari penyimpangan asumsi klasik. Uji asumsi klasik ini terdiri dari masalah normalitas, multikolinearitas, heteroskedastisitas, dan autokorelasi. Adapun cara yang digunakan untuk menguji penyimpangan asumsi klasik sebagai berikut:

\section{Uji Multikolinearitas}

Menurut Widarjono (2010:75), uji multikolinearitas bertujuan untuk menguji apakah model regresi mempunyai korelasi antar variabel bebas. Model yang baik, seharusnya tidak terjadi korelasi antar variabel bebas. Jika nilai koefisien determinasi $\mathrm{R}^{2}$ sangat tinggi, tetapi secara individual variabel-variabel bebas banyak yang tidak signifikan mempengaruhi variabel terikat, maka hal tersebut mengindikasikan adanya gejala multikolinearitas.

\section{Uji Autokorelasi}

Menurut Widarjono (2010:98), uji autokorelasi merupakan korelasi antara variabel gangguan satu observasi dengan variabel gangguan observasi lain. Untuk mengetahui ada tidaknya autokorelasi, maka digunakan metode Durbin Watson (DW Test). Hal ini sering muncul pada data time series. Salah satu pengujian gejala autokorelasi yaitu menggunakan uji Breusch Godfrey (Uji BG).

\section{Uji Heteroskedastisitas}

Menurut Ghozali (2009:105), uji heteroskedastisitas bertujuan menguji apakah dalam model regresi terdapat ketidaksamaan varian dari residual satu pengamatan ke pengamatan lain. Model regresi yang baik yaitu di dalam pengujiannya terjadi homoskedastisitas atau tidak terjadi heteroskedastisitas. Gejala heteroskedastisitas lebih sering terjadi pada data cross section.

\section{Uji Normalitas}

Menurut Ghozali (2009:111), uji normalitas bertujuan untuk menguji apakah dalam suatu model regresi linear berganda, variabel terikat dan variabel bebas keduanya mempunyai distribusi normal atau tidak. Sebagaimana penjelasan sebelumnya, dikatakan bahwa pada uji t dan uji $\mathrm{F}$ mengasumsikan nilai residual mengikuti distribusi normal. Apabila asumsi ini dilanggar, maka uji statistik menjadi tidak berlaku. 


\section{ANALISA DAN PEMBAHASAN}

\subsection{Uji Asumsi Klasik}

Sebelum dilakukan pengujian regresi yang bertujuan untuk melihat pengaruh SBI, JUB, Nilai Tukar, Pertumbuhan PDB, PDB dan Pengeluaran Pemerintah terhadap variabel terikat yakni inflasi, maka perlu dilakukan uji asumsi klasik. Pengujian ini dimaksudkan untuk memastikan bahwa model yang diperoleh benar-benar memenuhi asumsi dasar dalam analisis regresi yang meliputi: tidak terjadi multikolinearitas, tidak terjadi autokorelasi, dan tidak terjadi heteroskedastisitas.

\subsubsection{Uji Multikolinearitas}

Tabel 4.1.

Uji Multikolineritas

Hasil Pengujian Multikolinearitas Dengan Menggunakan Correlation Matrix

\begin{tabular}{|l|c|c|c|c|c|c|c|}
\hline & SBI & JUB & Nilai Tukar & $\begin{array}{c}\text { Pertumbuhan } \\
\text { PDB }\end{array}$ & PDB & $\begin{array}{c}\text { Pengeluaran } \\
\text { Pemerintah }\end{array}$ & Inflasi \\
\hline SBI & 1 & 0,0269 & 0,1401 & 0,0724 & 0,1228 & 0,2239 & $-0,0397$ \\
\hline JUB & 0,0269 & 1 & $-0,0196$ & $-0,3145$ & 0,5711 & 0,4771 & 0,4600 \\
\hline Nilai Tukar & 0,1401 & $-0,0196$ & 1 & $-0,0223$ & 0,0358 & 0,0891 & 0,0318 \\
\hline $\begin{array}{l}\text { Pertumbuhan } \\
\text { PDB }\end{array}$ & 0,0724 & $-0,3145$ & $-0,0223$ & 1 & $-0,5735$ & $-0,3015$ & $-0,0844$ \\
\hline PDB & 0,1228 & 0,5711 & 0,0358 & $-0,5735$ & 1 & 0,6984 & 0,0065 \\
\hline $\begin{array}{l}\text { Pengeluaran } \\
\text { Pemerintah }\end{array}$ & 0,2239 & 0,4771 & 0,0891 & $-0,3015$ & 0,6984 & & 1 \\
\hline Inflasi & $-0,0397$ & 0,4600 & 0,0318 & $-0,0844$ & 0,0065 & 0,0015 & 0,0015 \\
\hline
\end{tabular}

Sumber : data diolah, E-Views 5.1

\subsubsection{Uji Autokorelasi}

Tabel 4.2.

Hasil Pengujian Autokorelasi

Breusch-Godfrey Serial Correlation LM Test:

\begin{tabular}{cccc}
\hline \hline F-statistic & 0.529692 & Probability & 0.470131 \\
Obs*R-squared & 0.608002 & Probability & 0.435541 \\
& $=$
\end{tabular}


Berdasarkan hasil uji LM-test diatas, menunjukkan bahwa besarnya nilai probability lebih tinggi dari 0,05. Hal ini menunjukkan bahwa hasil estimasi tersebut tidak signifikan. Artinya dalam model yang diestimasi tersebut tidak mengandung korelasi serial (autokorelasi) antar faktor pengganggu (error term).

\subsubsection{Uji Heteroskedastisitas}

Tabel 4.3.

Hasil Pengujian Heteroskedasitas

White Heteroskedasticity Test:

\begin{tabular}{|c|c|c|c|}
\hline F-statistic & 0.543744 & Probability & 0.873890 \\
\hline Obs*R-squared & 7.344908 & Probability & 0.834005 \\
\hline
\end{tabular}

Berdasarkan tabel 4.4. diatas dengan menggunakan Uji White Heteroskedasticity Test diketahui nilai probability F-statistic $>0,05$. Hal ini dapat disimpulkan bahwa tidak terjadi heteroskedastisitas pada model regresi, sehingga model regresi layak dipakai untuk memprediksi inflasi.

\subsubsection{Uji Normalitas}

\section{Gambar 4.1.}

\section{Hasil Uji Normalitas}

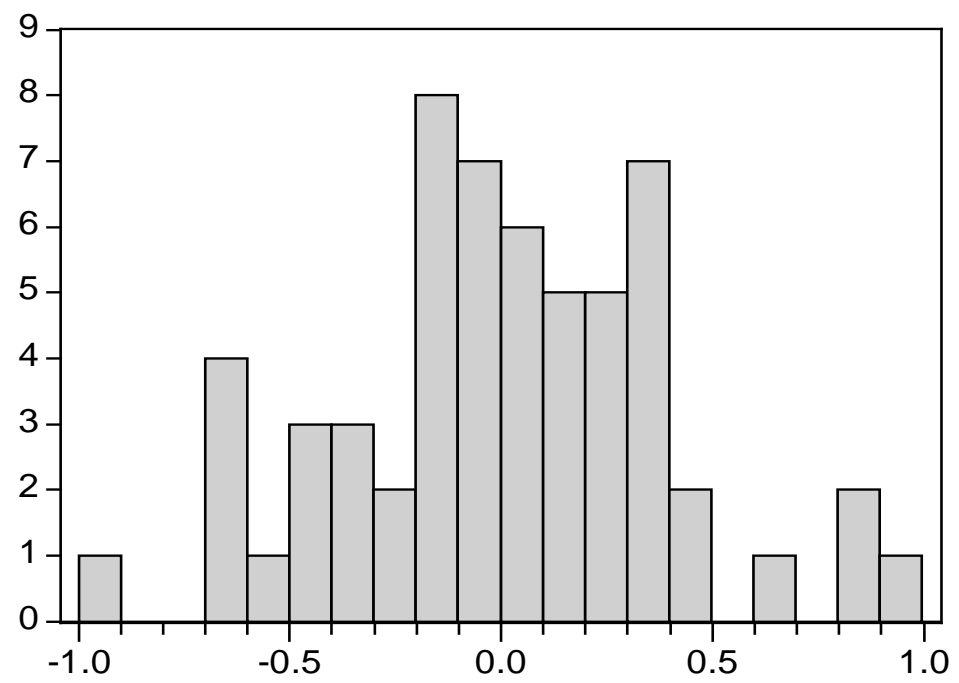

Series: Residuals

Sample 259

Observations 58

Mean

Median

Maximum

0.931789

Minimum

$-0.979295$

Std. Dev.

0.392270

Skewness

0.081966

Kurtosis

Sumber : data diolah, E-Views 5.1 
Berdasarkan hasil pengujian normalitas dengan menggunakan grafik histogram didapat hasil bahwa nilai probability memiliki nilai diatas alpha sebesar 0,05 ; sehingga model persamaan regresi memenuhi asumsi normalitas.

\subsubsection{Hasil Uji Akar Unit}

Masalah yang dihadapi dalam melakukan penelitian dengan menggunakan data ini adalah stasioner, Untuk itu terlebih dahulu dilakukan uji akar unit yang bertujuan untuk mengetahui apakah data tersebut stationer atau tidak, Penelitian menggunakan uji Dickey Fuller (DF) dan Augmented Dickey Fuller (ADF) dalam melakukan uji akar unit, Hasil pengujian akar unit ditunjukan pada tabel 4.2 dibawah ini:

Tabel 4.4

Hasil Uji Akar Unit

\begin{tabular}{|c|c|c|c|c|c|c|}
\hline Variabel & DF & $\mathbf{C V}$ & Kesimpulan & ADF & $\mathbf{C V}$ & Kesimpulan \\
\hline \multirow{3}{*}{ Inflasi } & \multirow{3}{*}{-8.585040} & -3.550396 & \multirow{3}{*}{$\begin{array}{c}\text { Stationer Pada } \\
\text { Derajat } 0\end{array}$} & \multirow{3}{*}{-8.505091} & -4.127338 & \multirow{3}{*}{$\begin{array}{c}\text { Stationer Pada } \\
\text { Derajat } 0\end{array}$} \\
\hline & & -2.913549 & & & -3.490662 & \\
\hline & & -2.594521 & & & -3.173943 & \\
\hline \multirow{3}{*}{ SBI } & \multirow{3}{*}{-3.199279} & -3.550396 & \multirow{3}{*}{$\begin{array}{l}\text { Tidak Stationer } \\
\text { Pada Derajat } 0\end{array}$} & \multirow{3}{*}{-3.276987} & -4.127338 & \multirow{3}{*}{$\begin{array}{l}\text { Tidak Stationer } \\
\text { Pada Derajat } 0\end{array}$} \\
\hline & & -2.913549 & & & -3.490662 & \\
\hline & & -2.594521 & & & -3.173943 & \\
\hline \multirow{3}{*}{ JUB } & \multirow{3}{*}{-10.00838} & -3.550396 & \multirow{3}{*}{$\begin{array}{c}\text { Stationer Pada } \\
\text { Derajat } 0\end{array}$} & \multirow{3}{*}{-9.954865} & -4.127338 & \multirow{3}{*}{$\begin{array}{l}\text { Stationer Pada } \\
\text { Derajat } 0\end{array}$} \\
\hline & & -2.913549 & & & -3.490662 & \\
\hline & & -2.594521 & & & -3.173943 & \\
\hline \multirow{3}{*}{ Nilai Tukar } & \multirow{3}{*}{-5.526441} & -3.550396 & \multirow{3}{*}{$\begin{array}{l}\text { Stationer Pada } \\
\text { Derajat } 0\end{array}$} & \multirow{3}{*}{-5.484335} & -4.127338 & \multirow{3}{*}{$\begin{array}{c}\text { Stationer Pada } \\
\text { Derajat } 0\end{array}$} \\
\hline & & -2.913549 & & & -3.490662 & \\
\hline & & -2.594521 & & & -3.173943 & \\
\hline \multirow{3}{*}{$\begin{array}{l}\text { Pertumbuhan } \\
\text { PDB }\end{array}$} & \multirow{3}{*}{-8.040639} & -3.550396 & \multirow{3}{*}{$\begin{array}{l}\text { Stationer Pada } \\
\text { Derajat } 0\end{array}$} & \multirow{3}{*}{-7.968815} & -4.127338 & \multirow{3}{*}{$\begin{array}{c}\text { Stationer Pada } \\
\text { Derajat } 0\end{array}$} \\
\hline & & -2.913549 & & & -3.490662 & \\
\hline & & -2.594521 & & & -3.173943 & \\
\hline \multirow{3}{*}{ PDB } & \multirow{3}{*}{-7.137143} & -3.552666 & \multirow{3}{*}{$\begin{array}{l}\text { Stationer Pada } \\
\text { Derajat } 0\end{array}$} & \multirow{3}{*}{-7.084100} & -4.130526 & \multirow{3}{*}{$\begin{array}{c}\text { Stationer Pada } \\
\text { Derajat } 0\end{array}$} \\
\hline & & -2.914517 & & & -3.492149 & \\
\hline & & -2.595033 & & & -3.174802 & \\
\hline \multirow{3}{*}{$\begin{array}{l}\text { Pengeluaran } \\
\text { Pemerintah }\end{array}$} & \multirow{3}{*}{-7.125859} & -3.550396 & \multirow{3}{*}{$\begin{array}{c}\text { Stationer Pada } \\
\text { Derajat } 0\end{array}$} & \multirow{3}{*}{-7.064560} & -4.127338 & \multirow{3}{*}{$\begin{array}{c}\text { Stationer Pada } \\
\text { Derajat } 0\end{array}$} \\
\hline & & -2.913549 & & & -3.490662 & \\
\hline & & -2.594521 & & & -3.173943 & \\
\hline
\end{tabular}

Sumber : data diolah, E-Views 5.1 


\subsubsection{Hasil Uji Kointegrasi}

Pengujian ini dilakukan untuk mengetahui ada atau tidaknya hubungan antara variabel bebas dan variabel tak bebasnya dalam jangka panjang, Engle dan Granger (1987) berpendapat bahwa dari tujuh uji statistik yang digunakan untuk menguji hipotesis null mengenai tidak adanya kointegrasi, uji CRDW (Cointegration-Regression Durbin-Watson), DF (Dickey-Fuller) dan ADF (Augmented Dickey-Fuller) merupakan uji yang paling disukai, Hasil uji ADF dari RESID01 adalah -8,318837 adalah lebih besar dari nilai kritisnya, Hal ini berarti terdapat hubungan yang signifikan (berkointegrasi) dalam jangka panjang antara inflasi dengan SBI, JUB, Nilai Tukar, Pertumbuhan PDB, PDB dan Pengeluaran Pemerintah.

\subsection{Pembahasan}

\subsubsection{Hasil Uji Error Correction Model (ECM)}

Tabel 4.5

Hasil Estimasi Model Regresi ECM Jangka Pendek t-1

Dependent Variable: DY

Method: Least Squares

Date: 10/19/12 Time: 13:06

Sample (adjusted): 359

Included observations: 57 after adjustments

\begin{tabular}{|c|c|c|c|c|}
\hline Variable & $\begin{array}{l}\text { Coefficien } \\
\mathrm{t}\end{array}$ & Std. Error & t-Statistic & Prob. \\
\hline C & -0.104746 & 0.076758 & -1.364617 & 0.1793 \\
\hline DX1 & 2.281831 & 5.368576 & 0.425035 & 0.6729 \\
\hline $\mathrm{DX} 1(-1)$ & -2.901586 & 5.264243 & -0.551188 & 0.5843 \\
\hline DX2 & 22.09024 & 4.546204 & 4.859051 & 0.0000 \\
\hline DX2(-1) & 8.195121 & 4.605949 & 1.779247 & 0.0821 \\
\hline DX3 & 1.459849 & 3.741608 & 0.390166 & 0.6983 \\
\hline DX3(-1) & 3.949085 & 3.821897 & 1.033279 & 0.3071 \\
\hline $\mathrm{DX} 4$ & -3.676449 & 2.738914 & -1.342301 & 0.1864 \\
\hline DX4(-1) & 1.499760 & 2.473747 & 0.606271 & 0.5475 \\
\hline DX5 & -23.24890 & 11.41996 & -2.035813 & 0.0478 \\
\hline DX5(-1) & 8.387614 & 10.34436 & 0.810839 & 0.4218 \\
\hline DX6 & 1.503778 & 3.294101 & 0.456506 & 0.6503 \\
\hline DX6(-1) & -3.788187 & 3.444660 & -1.099727 & 0.2774 \\
\hline R-squared & 0.413861 & \multicolumn{2}{|c|}{ Mean dependent var } & 0.007719 \\
\hline Adjusted R-squared & 0.254005 & \multicolumn{2}{|c|}{ S.D. dependent var } & 0.473396 \\
\hline S.E. of regression & 0.408877 & \multicolumn{2}{|c|}{ Akaike info criterion } & 1.246472 \\
\hline Sum squared resid & 7.355925 & \multicolumn{2}{|c|}{ Schwarz criterion } & 1.712431 \\
\hline Log likelihood & -22.52446 & \multicolumn{2}{|c|}{ F-statistic } & 2.588964 \\
\hline Durbin-Watson stat & 2.440444 & \multicolumn{2}{|c|}{ Prob(F-statistic) } & 0.010757 \\
\hline
\end{tabular}

Sumber : data diolah, E-Views 5.1 
Tabel 4.6

Hasil Estimasi Model Regresi ECM Jangka Pendek t-2

Dependent Variable: DY

Method: Least Squares

Date: 10/19/12 Time: 13:15

Sample (adjusted): 459

Included observations: 56 after adjustments

\begin{tabular}{lllll}
\hline \hline \multicolumn{4}{l}{ Variable } & \multicolumn{2}{l}{ Coefficien } & & \\
& $\mathrm{t}$ & Std. Error & t-Statistic & Prob. \\
\hline \hline C & -0.029703 & 0.075825 & -0.391727 & 0.6972 \\
DX1 & 8.143243 & 4.328133 & 1.881468 & 0.0667 \\
DX1(-2) & -12.41287 & 4.373935 & -2.837919 & 0.0069 \\
DX2 & 16.19556 & 4.079363 & 3.970121 & 0.0003 \\
DX2(-2) & -4.518546 & 4.269274 & -1.058387 & 0.2958 \\
DX3 & 1.314027 & 3.900624 & 0.336876 & 0.7378 \\
DX3(-2) & -3.196193 & 3.975539 & -0.803965 & 0.4258 \\
DX4 & -5.059998 & 2.677740 & -1.889653 & 0.0656 \\
DX4(-2) & 2.850364 & 2.411385 & 1.182044 & 0.2437 \\
DX5 & -26.69945 & 11.10562 & -2.404139 & 0.0206 \\
DX5(-2) & 7.642493 & 9.979231 & 0.765840 & 0.4480 \\
DX6 & 2.050823 & 3.400164 & 0.603154 & 0.5496 \\
DX6(-2) & 5.160819 & 3.321912 & 1.553569 & 0.1276 \\
\hline \hline R-squared & 0.465192 & Mean dependent var & 0.011607 \\
Adjusted R-squared & 0.315944 & S.D. dependent var & 0.476761 \\
S.E. of regression & 0.394318 & Akaike info criterion & 1.176816 \\
Sum squared resid & 6.685927 & Schwarz criterion & 1.646987 \\
Log likelihood & -19.95085 & F-statistic & 3.116895 \\
Durbin-Watson stat & 2.406267 & Prob(F-statistic) & 0.002991 \\
\hline \hline
\end{tabular}

Sumber : data diolah, E-Views 5.1

\section{SIMPULAN DAN SARAN}

\subsection{Simpulan}

Berdasarkan hasil analisa dan pembahasan yang telah diuraikan sebelumnya, maka dapat ditarik beberapa simpulan sebagai berikut:

1. Untuk variabel SBI dengan nilai t hitung sebesar $1,881468<$ dari nilai t tabel sebesar 2,0057, sehingga t hitung $<\mathrm{t}$ tabel $(1,881468<2,0057)$ dan nilai signifikan sebesar 0,0667 $>0,05$, sehingga Ho diterima artinya variabel SBI tidak berpengaruh signifikan terhadap inflasi. Sedangkan variabel SBI t-2 dengan nilai t hitung sebesar $-2,837919>$ dari nilai $t$ tabel sebesar -2,0057, sehingga thitung $>\mathrm{t}$ tabel $(-2,837919>-2,0057)$ dan nilai signifikan 
sebesar $0,0069<0,05$, sehingga Ho ditolak artinya variabel SBI t-2 berpengaruh signifikan terhadap inflasi.

2. Untuk variabel JUB dengan nilai t hitung sebesar 3,970121 > dari nilai t tabel sebesar 2,0057, sehingga t hitung $>$ t tabel $(3,970121>2,0057)$ dan nilai signifikan sebesar 0,0003 $<0,05$, sehingga Ho ditolak artinya variabel JUB berpengaruh signifikan terhadap inflasi. Sedangkan variabel JUB t-2 dengan nilai t hitung sebesar $-1,058387<$ dari nilai t tabel sebesar -2,0057, sehingga t hitung $<\mathrm{t}$ tabel $(-1,058387>-2,0057)$ dan nilai signifikan sebesar 0,2958 $>0,05$, sehingga Ho diterima artinya variabel JUB t-2 tidak berpengaruh signifikan terhadap inflasi.

3. Untuk variabel Nilai Tukar dengan nilai t hitung sebesar $0,336876<$ dari nilai t tabel sebesar 2,0057, sehingga t hitung $<$ t tabel $(0,336876<2,0057)$ dan nilai signifikan sebesar $0,7378>0,05$, sehingga Ho diterima artinya variabel Nilai Tukar tidak berpengaruh signifikan terhadap inflasi. Sedangkan variabel Nilai Tukar t-2 dengan nilai t hitung sebesar $-0,803965<$ dari nilai t tabel sebesar $-2,0057$, sehingga t hitung $<$ t tabel $(-0,803965$ $<-2,0057$ ) dan nilai signifikan sebesar 0,4258 > 0,05, sehingga Ho diterima artinya variabel Nilai Tukar t-2 tidak berpengaruh signifikan terhadap inflasi.

4. Untuk variabel Pertumbuhan PDB dengan nilai $t$ hitung sebesar $-1,889653<$ dari nilai $t$ tabel sebesar 2,0057, sehingga t hitung $<\mathrm{t}$ tabel $(-1,889653<-2,0057)$ dan nilai signifikan sebesar 0,0656 $>0,05$, sehingga Ho diterima artinya variabel Pertumbuhan PDB tidak berpengaruh signifikan terhadap inflasi. Sedangkan variabel Pertumbuhan PDB t-2 dengan nilai t hitung sebesar $1,182044<$ dari nilai t tabel sebesar 2,0057, sehingga t hitung $<\mathrm{t}$ tabel $(1.182044<2.0057$ ) dan nilai signifikan sebesar 0,2437 > 0.05 sehingga Ho diterima artinya variabel pertumbuhan PDB tidak berpengaruh signifikan terhadap inflasi.

5. Untuk variabel PDB dengan nilai t hitung sebesar $-2.404139>$ dari nilai t tabel sebesar 2,0057, sehingga t hitung $>\mathrm{t}$ tabel $(-2,404139>2,0057)$ dan nilai signifikan sebesar $0,0206<0,05$, sehingga Ho ditolak artinya variabel PDB berpengaruh signifikan terhadap inflasi. Sedangkan variabel PDB t-2 dengan nilai t hitung sebesar $0,765840<$ dari nilai t tabel sebesar 2,0057, sehingga $t$ hitung $<\mathrm{t}$ tabel $(0,765840<2,0057)$ dan nilai signifikan sebesar $0,4480>0,05$, sehingga Ho diterima artinya variabel PDB tidak berpengaruh signifikan terhadap inflasi.

6. Untuk variabel Pengeluaran Pemerintah dengan nilai t hitung sebesar 0,603154 $>$ dari nilai t tabel sebesar 2,0057, sehingga t hitung $>$ t tabel 0,603154 > 2,0057 ) dan nilai signifikan sebesar 0,5496 > 0,05, sehingga Ho diterima artinya variabel Pengeluaran Pemerintah tidak berpengaruh signifikan terhadap inflasi. Sedangkan variabel Pengeluaran Pemerintah t-2 dengan nilai t hitung sebesar 1,553569 < dari nilai t tabel sebesar 2,0057, sehingga t hitung $<\mathrm{t}$ tabel $(1,553569<2,0057)$ dan nilai signifikan sebesar 0,1276 >0,05 sehingga Ho diterima artinya variabel Pengeluaran Pemerintah t-2 tidak berpengaruh signifikan terhadap inflasi

\subsection{Saran}

Berdasarkan hasil simpulan yang telah diuraikan, maka penulis memberikan beberapa saran sebagai berikut:

1. Bagi Investor yang ingin melakukan investasi sebaiknya memperhatikan pergerakan tingkat suku bunga SBI 2 bulan sebelumnya, karena memberikan pengaruh terhadap inflasi.

2. Pemerintah harus meninjau kembali dalam hal pemasokan jumlah uang beredar agar dapat menstabilkan pertumbuhan inflasi yang tinggi. 
3. Dalam jangka pendek dan jangka panjang penerapan inflation targeting framework di Indonesia selama rejim nilai tukar terbukti berhasil menurunkan pengaruh perubahan nilai tukar.

\section{DAFTAR PUSTAKA}

Ajija, Shochrul Rohmatul, et.al. 2011. Cara Cerdas Menguasai EViews. Salemba Empat, Jakarta. Boediono, 1999. Efektifitas Kebijakan Suku Bunga Dalam Rangka Stabilisasi Rupiah. Di Masa Krisis., Ekonomi Makro. Edisi ke-4, BPFE., Yogyakarta.

1999. Teori Pertumbuhan Ekonomi,seri Sinopsis, Edisi Pertama,. Cetakan Pertama BPFE, Yogyakarta

--------,. 2001. Ekonomi Makro. Edisi-4. penerbit BPFE, Yogyakarta

Basri, 2005. Keuangan Negara dan Analisis Kebijakan Utang Luar Negeri. Jakarta

Dumairy, 1997. Perekonomian Indonesia , Penerbit Erlangga. Jakarta.

Ensiklopedi Nasional Indonesia, 1991, Jakarta : PT Cipta Adi Pustaka.

Hamdy Hardi, 1999. Ekonomi Internasional Buku Kedua Teori \& Kebijakan Keuangan Internasional , Jakarta.

Haryanti, Enny, 2004. Pengaruh tingkat bunga dan inflasi terhadap fluktuasi nilai tukar rupiah, Jurnal Manajemen dan Akuntansi, Vol VIII No.2 Oktober - Nopember 2004, Jakarta.

Hasan Basri, 2005. Bisnis Pengantar, Yogyakarta : BPFE-Yogyakarta

Khalwaty, 2000. Perkembangan Inflasi Nasional tahun. 2006, 2007, 2008. Inflasi dan Solusinya. Cetakan pertama. PT. Gramedia Pustaka. Utama,. Jakarta

Lesmana, Iwan. 2003 Pengaruh Suku Bunga Deposito, Inflasi dan Nilai Tukar Rupiah terhadap Suku Bunga Kredit Modal Kerja, Jurnal Manajemen dan Akuntansi Vol.VII No. 1 April, Mei, 2003 Jakarta.

Mangkoesoebroto, Guritno, 1994. Kebijakan Ekonomi Publik Di Indonesia Gramedia Pustaka Utama, Jakarta.

Nopirin, 1992. Ekonomi Moneter Buku 2. Analisis pengaruh inflasi dan suku bunga SBI

Oesman, Helma, 1999. Penerapan kebijakan nilai tukar di Indonesia, Ilmu dan budaya, Jakarta. PT Gramedia Pustaka Utama, Jakarta.

Putong, Iskandar, 2000. Pengantar Ilmu Ekonomi Mikro dan Makro, Penerbit Ghalia Indonesia, Jakarta.

Suminto, 2004. Pengelolaan APBN Dalam Sistem Manajemen Keuangan Negara, Jakarta.

Wiranta, 1997. "Kaitan Antara Inflasi, Tingkat Suku Bunga dan. Pertumbuhan Ekonomi : Suatu Ulasan Makro”, dalam Jurnal-. Keuangan dan Moneter, Jakarta.

Hamzah, Mhd. Zilal dan Sofilda, Leonora 2006. Analisa pengaruh jumlah uang beredar, nilai tukar rupiah dan pengeluaran pemerintah terhadap inflasi di Indonesia, Jurnal Kebijakan Ekonomi, Jakarta 